\title{
Ensuring sustainable spatial development from the perspective of land relations regulation
}

\author{
Dzhamilya Saralinova*, Diba Dokhkilgova \\ Kadyrov Chechen state University, A. Sheripova, 32, 364093 Grozny, Russia
}

\begin{abstract}
Solving new problems of sustainable development of society and territories requires improving the regulation of land relations to meet the managerial, production and technological needs of society. Improving the efficiency of regulating land relations and the use of lands of all categories in the context of their global degradation is one of the most important socio-economic problems in modern conditions. To solve the problems of land management, their rational use and protection, optimization of agricultural production, taking into account the environmental safety of products, an integrated approach to the regulation of land relations is needed, which is provided by the system of land management and land monitoring. The need to improve land relations management is obvious and indisputable, and the topic of the work seems relevant and timely. The purpose of the work is to develop practical recommendations for improving the mechanism of land relations management at the state and municipal level. Management decisionmaking should be based on the principles of strategic and tactical planning of innovation activities, taking into account the geopolitical, economic and socio-cultural specifics of the territory.
\end{abstract}

\section{Introduction}

One of the priorities of regional government bodies in recent years remains the purposeful coordination of the work of the sectoral executive authorities of the subject of the Russian Federation to optimize the composition of the property complex and bring it in line with the powers of the region. Priorities, goals, tasks of socio-economic development of the subject of the Russian Federation and the directions of activities for their implementation are approved by the resolution of the legislative body of the subject of the Russian Federation.

The existing distribution of the land fund by land categories, land users and land requires improvement. To do this, in the specific conditions of the regions, it is necessary to develop a methodology for monitoring land plots and land management aimed at a multifactorial assessment of land, taking into account the peculiarities of both natural and climatic factors and human economic activity in the region, the use of innovative technologies taking into account modern energy and environmental aspects. The impact of innovations on the sustainable development of society was noted in the innovative works of A. Smith, which describes the relationship between the theory of exchange and the theory

*Corresponding author: saralinova@list.ru 
of production. Following him, D. Ricardo justified the sustainable development of the economy based on innovations in agriculture and resource conservation. Today, the global scarcity of resources and the presence of planetary environmental problems has become obvious. The obvious alternative is: a global catastrophe due to violations of global homeostasis, or a transition to a fundamentally different mode of civilization development.

As one of the main tools for regulating land relations, it is necessary to consider the mechanism for resolving issues of local importance through the powers assigned to the governing bodies at the municipal level. Considering the issues of land relations management, it should be remembered that most municipalities are rural territories. Evaluation of the efficiency of land use is an actual indicator of municipal management.

Identification and analysis of the direction of existing investment flows at the global, national and regional levels becomes a key element of strategic planning of the activities of government bodies at the regional and municipal levels. The subject of attention are such areas as: access to key markets; ownership of land plots, their availability and liquidity; efficiency of investments in land plots and taxation of real estate; issues of land legislation; problems of effective use of municipal lands and rural settlements; price level and other aspects.

\section{Materials and Methods}

On the basis of theoretical and methodological provisions and the regulatory framework of the Russian Federation, relying on a systematic approach, comparative analysis, informal modeling and comparison, systematization of data, the peculiarities of regulating issues of ownership and land relations, the disposal of land plots are investigated. As a result of the generalization of the analyzed materials, it was revealed that at all levels of land management, modern promising tools for the qualitative organizational and economic development of territories and rational disposal of land plots as a certain basis for their economic growth are not fully applied. This made it possible to identify problems in the implementation of powers to dispose of land plots at the municipal level and to justify the priority directions of their development.

State regulation of the restructuring of land plots is carried out with the help of anticrisis management tools and measures within the framework of land policy. Thus, regulatory documents have been developed that contain criteria for the insolvency of tenants and owners and recommended management methods, such as a competitive mechanism and market sale of land, privatization of land plots. Spatial development of the economy is a state task, but its solution is achieved with the help of the state or municipal entity in determining the territorial location of the land plot intended for the placement of a specific object, in determining the purposes of using a specific site, its area, planned assistance to investors in providing infrastructure facilities, etc. In this regard, the approach of the Ministry of Economic Development of Russia seems justified, which determines the relationship between the purpose of a group of real estate objects and infrastructure components, land plots, premises of various profiles with the implementation of production and the creation of conditions for effective work.

\section{Results and Discussion}

The Russian Federation is a country with the largest territory and land area in the world, which refers to the factors of the "inner strength" of our state, along with other features and advantages: human, material, spiritual, natural. But, first of all, the territory of Russia 
requires a rational approach in management, both in rural settlements and in existing urbanized territories [1].

The management of the land fund of the Russian Federation is a separate area of public administration.

The land fund management bodies are integrated into an integrated system (Figure 1).

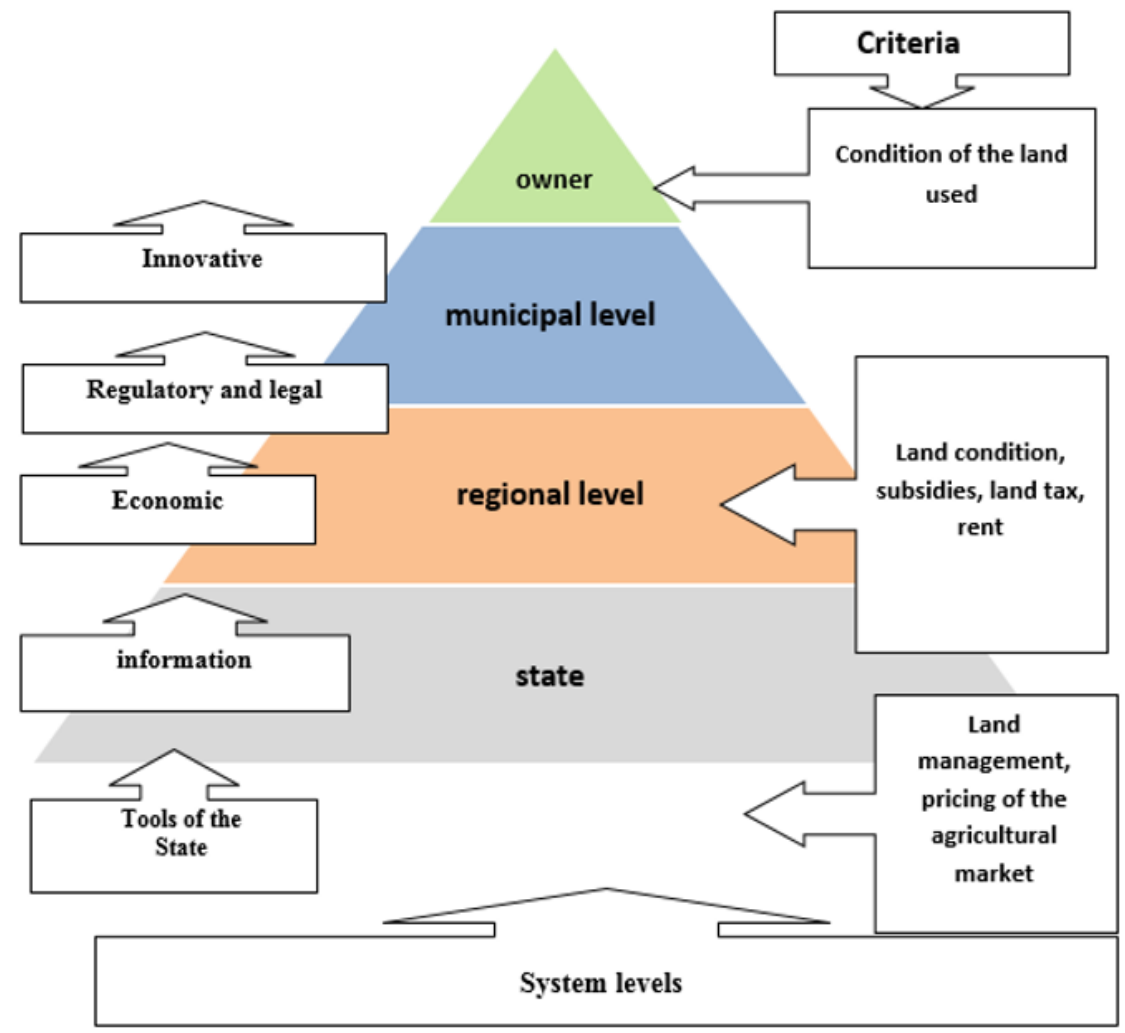

Fig. 1. Land Fund management system of Russia

The powers of Russia in the field of land relations include:

1)establishment of the foundations of federal policy in the field of regulation of land relations;

2)development and implementation of federal programs for the use and protection of land;

3)establishment of restrictions on the rights of owners of land plots, land users, landowners, tenants of land plots, as well as restrictions on the turnover of land plots;

4)management in the field of land monitoring, land supervision and land management;

5)establishment of the procedure for withdrawal, reservation of land and withdrawal of land plots for state and municipal needs, etc.

The main goal and direct competence of regional and municipal authorities are issues of the standard of living of the population. Regional ownership is one of the tools for solving problems in this area [2].

The subjects of the Russian Federation manage and dispose of land plots owned by the subjects of the Russian Federation.

One of the priorities of the regional government bodies in recent years remains the purposeful coordination of the work of the sectoral executive authorities of the subject of the Russian Federation to optimize the composition of the republican property complex and 
bring it in line with the powers of the region. The powers of the subjects of the Russian Federation include the development and implementation of regional programs for the use and protection of lands located within the borders of the subjects of the Russian Federation; reservation, withdrawal of land plots for the needs of the subjects of the Russian Federation; other powers that are not attributed to the powers of the Russian Federation or to the powers of local self-government bodies.

Priorities, goals, tasks of socio-economic development of the subject of the Russian Federation and the directions of activities for their implementation are approved by the resolution of the legislative body of the subject of the Russian Federation, which is reflected, as a rule, in strategic planning documents [3]. The main functions for their implementation are performed by the executive body of state power - the Ministry of Property and Land Relations. The actions and efforts of municipalities are aimed at completing the work on the cadastral registration of all lands and the delimitation of ownership rights to them. From these positions, the main emphasis is placed on the development of strategic and medium-term plans for the use of productive lands.

All participants in economic activity should be involved in achieving sustainable development. This can be realized thanks to the participation of the state, business and the financial sector in the process. At the same time, each of them plays a certain role - the state gives signals and creates conditions for conducting economic activity. The financial sector directs cash flows to the necessary activities, and the business implements the achievement of sustainable development in practice. Thus, the interaction of all three parties will allow achieving social and environmental results along with financial returns [4].

According to the norms for crediting tax revenues to the budget, indicated in the Budget Code of the Russian Federation, land tax and property tax of individuals are received in full to the municipal budget.

Currently, the main source of income for local budgets in the Russian Federation is property taxation. It should be noted that the tax revenues of local budgets are differentiated depending on the type of municipality. Thus, the budget of municipal districts receives these taxes levied only on inter-settlement territories.

At the municipal level, the authorities can take measures to optimize the established tax benefits for local taxes that are not associated with an increase in investments in the territory of the municipality or region, by assessing their effectiveness and including them in the system of assessing the quality of regional and municipal finance management. For municipalities, both direct payments from the federal budget and the budget of a constituent entity of the Russian Federation can be used, aimed at the introduction of these technologies by local governments (in the form of inter-budget transfers directed specifically to a specific municipality), and financial and legal incentives, when the amount of budget funds allocated from a higher budget increases depending on the timing of the introduction of technologies, the installation of specific programs, as well as the coverage of users involved and using the necessary technologies.

In addition, there is a need for management in the direction of limiting the concentration of land plots among large owners and land users. One of the most important conditions for the development of this sphere is a developed infrastructure of the land market and a low level of transaction costs.

Problems in the implementation of the powers to involve real estate objects in economic turnover by executive bodies of state power and local self-government bodies are:

- low investment attractiveness of objects;

- a large degree of wear of objects;

- territorial remoteness of objects from cities and district centers;

- lack of a source of financing for the involvement of objects in economic turnover; 
- low quality of urban planning documentation;

- lack of a developed system of engineering communications.

As tools for involving unused or inefficiently used land plots in economic turnover, the following are used:

- transfer of unused land plots from one balance holder to another;

- gratuitous transfer of land plots to federal ownership, to the ownership of a subject of the Russian Federation;

- transfer of unused land plots for rent;

- giving consent to the sale of land plots;

- withdrawal of unused land plots in order to implement it through privatization;

- provision of land plots both at auction and without bidding (including for the implementation of investment projects)-

- other solutions (including attracting investors by concluding concession agreements, etc.).

The implementation of the above measures will contribute to the rational use of real estate objects and land plots owned by the subject of the Russian Federation, as a result of:

- identification and involvement in the economic turnover of unused real estate objects, including land plots;

- identification and elimination of inconsistencies between the layouts of existing technical passports and the actual location of premises in buildings;

- cadastral registration, state registration of the rights of unaccounted and unregistered land plots and/or real estate objects;

- identification and elimination of violations in the execution of contracts of gratuitous use, lease agreements of property of the subject of the Russian Federation.

On the other hand, the further development of various forms of activity largely determines the creation of significant financial and administrative conditions. Indeed, the spatial development of the economy is a state task, but its solution is achieved with the help of the state or municipal entity in determining the territorial location of the land plot intended for the placement of a specific object, in determining the purposes of using this site, its area, planned assistance to investors in providing infrastructure facilities, etc. The task of organizing, in particular, the management and development of the land management system allows us to determine the vector of the direction of progressive development of land relations.

The creation of a favorable investment climate is usually based on the desire of the authorities to implement the goals of national and regional economic development. The following approaches can be used:

- financial incentives (direct subsidies, grants and loans);

- tax instruments (tax holidays and reduced tax rates)-

- other approaches, including subsidies for the purchase of land, the use of infrastructure and various services.

It should be noted that experts consider it expedient to legally delimit the regulatory role of state bodies, on the one hand, and the areas of activity of owners, developers and business administrators, on the other hand.

It is obvious that the implementation of the intended goals is associated with the need to accumulate significant financial and administrative resources [5]. Diverse and rich experience the existing structure of the organization requires the definition and clarification of further directions of development.

The need to involve unused or inefficiently used land plots in economic turnover requires the involvement of certain instruments of influence, in particular, the transfer of unused land plots to lease or from one balance sheet holder to another is considered 
effective, as well as the withdrawal of unused land plots for the purpose of its implementation through privatization. It is also possible to sell land plots, including through bidding, and without bidding (for example, for the implementation of investment projects). In addition, it is possible to attract investors by concluding concession agreements and so on.

An important aspect of the disposal of land plots is their role as the basis for the organization of business activity, especially when conducting production activities, including by enterprises of the transport and communication structure of the region, energy, water supply and waste disposal systems [6].

Improving the mechanism of land management and relations at the municipal level is advisable in the following areas:

- develop strategic and medium-term plans for the use of productive lands;

- complete the cadastral registration of all lands and the delimitation of ownership rights to them;

- limit the concentration of land plots among large owners and land users;

- to develop the infrastructure of the land market and reduce the level of transaction costs.

To improve the current situation with land plots, it is proposed to carry out the following measures: to develop regulatory documentation on registration requirements, with the presence of penalties for non-compliance with the requirements; to include in the annual monitoring indicators such as land EC, DCT, private and comprehensive assessments of anthropogenic impact on the territory.

It is also necessary to carry out annual proper monitoring of:

- $\quad$ use of land plots;

- $\quad$ preservation of soil fertility and humus layer of soil;

- $\quad$ organization of optimal recreation of the land, reclamation and conservation of

land;

- chemical treatment against pests and diseases in the areas;

- regular and timely implementation of the best available technologies in production.

In order to improve the system of land management in the region, it is advisable to:

- identify among the existing land plots those that are not properly formed;

- systematize the work on the formation of land plots and the establishment or modification of their permitted use;

- to form the missing information base and improve the existing system of urban planning activities.

It is necessary to develop a functional integrated approach to the regulation of land relations under the control of management bodies, which is more in line with the new production relations associated with the conditions of a market economy.

\section{Conclusion}

A pragmatic approach to determining the powers of authorities to dispose of land plots with an emphasis on the methodology of a comprehensive assessment of land use will increase the competitive advantages of the subjects of the Russian Federation, municipal and other administrative-territorial entities of the country within the framework of ensuring the effective use of land resources.

The state investment policy to support investment activities in each region has its own characteristics due to the innovation policy of the region, natural and climatic conditions, the availability of energy resources, the features of the infrastructure of investment 
activities, the existing production, personnel and innovation potentials, the geographical location of the region, the environmental and demographic situation, the investment attractiveness of the region. At the same time, the goals and objectives of the regional investment policy in the field of innovation, the forms and methods of its implementation may not coincide in different subjects of the Russian Federation [7].

The criterion of continuous development links regional sustainability with sustainable development (improving the lives of people around the world), and future research should focus on accelerating economic development through policy, allocation of funds, or simply creating a basis for the sustainability of all processes [8].

In order to increase the efficiency of land use of all categories in the conditions of their global degradation, all subjects of land relations need to accumulate information about the state and nature of land use, have an idea of changes in this area and see prospects for their further development.

World practice shows that effective innovative development is possible only in a managed innovation system. Management decision-making should be based on the principles of strategic and tactical planning of innovation activities, taking into account the geopolitical, economic and socio-cultural specifics of the territory. A comprehensive solution to the task offers comprehensive, timely and accurate information about the management object. Therefore, it is necessary to develop and organize monitoring of innovation processes in the region.

This approach eliminates the contradictions between the unsystematic use of land and the need for systematization of methods and technologies for regulating land relations as a complex complex, which is dictated by the process of widespread digitalization, the development of science and technology in general. The need for the early introduction of electronic document management in the field of land relations regulation in the digital economy implies the allocation of appropriate financial resources for this. Various incentives can be used for private subjects of financial and legal relations, for example, tax and legal incentives for the introduction and use of digital technologies. The issue of introducing digital technologies for municipalities is particularly acute, since, as a rule, they do not have their own financial resources to spend on this area. Another direction of the formation of the financial and legal status of municipalities is to expand the opportunities of citizens to participate in the financial activities of municipalities, including their involvement in the budget process, which, with well-structured work, contributes to increasing public confidence in local self-government bodies and the financial and legal policy pursued by the state. The study of the forms of such participation in the framework of financial law is just beginning and requires further development.

The application of geomonitoring methods as the basis of territorial development and management of territories is also justified. Thus, the solution of the problem is achievable on the basis of a complex of scientific research and practical work aimed at systematization and improvement of the system of regulation of land relations and sustainable development of territories during the digital transformation of the economy as a whole.

\section{References}

1. N.G. Zhavoronkova, G.V. Vypkhanova, Lex Russica, 2(171), 50 (2021)

2. E.A. Korotaeva, Bulletin of the Udmurt University. Economics and Law Series, 27(4), 104 (2017)

3. A.V. Denisova, Society and law, 4(41), 95 (2012) 
4. A. Beksultanova, T. Magomadova, and M. Barzaeva, Proceedings of the International Scientific and Practical Conference on Sustainable Development of Regional Infrastructure, 298 (2021)

5. Yu.Yu. Yurkova, Bulletin of the Voronezh State Agrarian University, 4(59), 250 (2018)

6. O.B. Mezenina, Moscow Economic Journal, 9, 1 (2020)

7. L.N. Roshchina, Finance and credit, 14(494), 7 (2012)

8. M. Szabo, M.S. Csete, T. Palvolgyi, European Journal of Sustainable Development, 7(1), 395 (2018) 